\title{
Antidiscrimination Class Actions Under the Federal Rules of Civil Procedure: The Transformation of Rule 23(b)(2)
}

[W]e often miss the persistent and inevitable tension between procedure generalized across substantive lines and procedure applied to implement a particular substantive end. ... . [The] demands of particular substantive objectives . . . cannot be served except through the ... shaping ... of process to ... an area of law.... [T] he integrity of the Federal Rules ... [is] akin to the structure of a coastline. Washed by litigation, the line must shift and shape itself to tides and storms. ${ }^{1}$

This Note is a case study of the impact of substantive law ${ }^{2}$ upon a procedural rule that had an uncertain foundation and was therefore

1. Cover, For James Wm. Moore: Some Reflections on a Reading of the Rules, 84 YALE L.J. 718,718 (1975). In addressing the molding of procedural rules by substantive law, this Note examines a phenomenon that is the obverse of that captured in Sir Henry Maine's famous observation: "substantive law has at first the look of being gradually secreted in the interstices of procedure." H. MAINe, EARLY LAW AND Custom 389 (1891); see Hazard, The Effect of the Class Action Upon the Substantive Law, 58 F.R.D. 307, 307 (1973) ("Substantive law is shaped and articulated by procedural possibilities."); Note, The Impact of Class Actions on Rule 10b-5, 38 U. CHI. L. REv. 337, $337-42$ (1971) (examining expansion in liability under $\S 10(\mathrm{~b})$ of Securities Exchange Act of 1934, 15 U.S.C. $\S 78 \mathrm{j}(\mathrm{b})$ (1976), and SEC Rule 10b-5, 17 C.F.R. $\$ 240.10 \mathrm{~b}-5$ (1977), prompted by use of class action device and challenging notion of substance-procedure dichotomy).

2. Title VII of the Civil Rights Act of 1964, 42 U.S.C. $\$ \$ 2000 \mathrm{e}$ to $2000 \mathrm{e}-17$ (Supp. V 1975), provides the principal substantive component of the substance/procedure interaction examined in this Note. However, the analysis developed here is meant to apply to all class actions in which the underlying cause of action is supplied by antidiscrimination law. See note 11 infra. Title VII prohibits employment discrimination based on race, sex, national origin, or religion, 42 U.S.C. $\$ 2000 \mathrm{e}-2$ (Supp. V 1975), and provides for injunctive relief, reinstatement, and hiring with or without back pay to remedy unlawful employment practices, $i d$. $\$ 2000 \mathrm{e}-5(5)(\mathrm{g})$. The statutory enforcement scheme mandates two conditions precedent to a private suit to enforce rights under Title VII: the potential plaintiff must file a charge specifying the nature of the alleged violations with the Equal Employment Opportunity Commission (EEOC), id. $\$ 2000 \mathrm{e}-5(\mathrm{e})$, and the plaintiff must obtain a right-to-sue letter issued by the Commission after it either dismisses the charge following investigation and a determination of no reasonable cause to believe the charge true, or, without such determination and dismissal, fails itself to file a civil suit or to enter into a conciliation agreement to which the complaining employee is a party within 180 days of receipt of the charge, $i d$. $\$ 2000$ e-5(f)(1).

The EEOC charge and the right-to-sue letter are designed to give the agency an opportunity to investigate and conciliate the dispute. Investigation and conciliation by the Commission are not, however, statutorily established, jurisdictional prerequisites to a private suit. See McDonnell Douglas Corp. v. Green, 411 U.S. 792, 798-800 (1973) (finding of reasonable cause in EEOC investigation not necessary for plaintiff to bring suit); Carr v. Conoco Plastics, Inc., 423 F.2d 57, $61-62$ (5th Cir.), cert. denied, 400 U.S. 951 (1970) (Commission's failure to investigate and conciliate does not prevent plaintiff from seeking 
especially susceptible to the "shaping ... of process"3 by social policy objectives. Federal Rule of Civil Procedure 23(b)(2), ${ }^{4}$ which governs the injunctive class action, is assumed to be relatively unproblematic; ${ }^{5}$ the class action literature ${ }^{6}$ has directed critical scrutiny primarily to

judicial determination of his rights). The EEOC charge is not filed as a preliminary pleading for a lawsuit; it is only intended to invoke the EEOC administrative process. Although a plaintiff representing a class must have filed the triggering EEOC charge, the class can include parties who did not themselves file EEOC charges. Albemarle Paper Co. v. Moody, 422 U.S. 405,414 n.8 (1975). Thus, under the Title VII statutory scheme, FED. R. Civ. P. 23 determines the propriety and scope of a class action challenging employment discrimination. For discussions of the administrative mechanism established by Title VII, see Peck, The Equal Employment Opportunity Commission: Developments in the Administrative Process 1965-1975, 51 Wash. L. REv. 831 (1976); Sullivan, The Enforcement of Title VII: Meshing Public and Private Efforts, 71 Nw. L. REv. 480 (1976).

3. Cover, supra note 1 , at 718 .

4. FED. R. Crv. P. 23(b) divides class actions into three types, delineated respectively in subdivisions $23(\mathrm{~b})(\mathrm{l}),(\mathrm{b})(2)$, and (b)(3):

(b) Class Actions Maintainable. An action may be maintained as a class action if the prerequisites of subdivision (a) are satisfied, and in addition:

(l) the prosecution of separate actions by or against individual members of the class would create a risk of

(A) inconsistent or varying adjudications with respect to individual members of the class which would establish incompatible standards of conduct for the party opposing the class, or

(B) adjudications with respect to individual members of the class which would as a practical matter be dispositive of the interests of the other members not parties to the adjudications or substantially impair or impede their ability to protect their interests; or

(2) the party opposing the class has acted or refused to act on grounds generally applicable to the class, thereby making appropriate final injunctive relief or corresponding declaratory relief with respect to the class as a whole; or

(3) the court finds that the questions of law or fact common to the members of the class predominate over any questions affecting only individual members, and that a class action is superior to other available methods for the fair and efficient adjudication of the controversy.

For general discussions of the three types of class actions, see Advisory Comm. Note, 39 F.R.D. 98 (1966); 3B Moore's Federal Practice (fI 23.31[1], .35, .40, .45 (2d ed. 1978); 7A C. Wright \& A. Miller, Federal Practice and Procedure $\$ \$ 1772-1780$ (1972); Kaplan, Continuing Work of the Civil Committee: 1966 Amendments of the Federal Rules of Civil Procedure I, 81 HARv. L. REv. 356, 375-400 (1967).

5. See, e.g., A. Miller, An Overview of Federal Class Actions: Past, Present, and Future 4 (1977) ("difficulties with the functioning of Rule 23 ... center around the (b)(3) category of cases and do not involve (b)(1) or (b)(2) cases"); id. at 46 ("Rule 23(b)(2) .. . really has not generated any significant difficulties, even though more cases probably have been brought under this category than under any of the others in subdivision (b)."

6. Developments in the Law-Class Actions, 89 Harv. L. Rev. 1318, 1324 \& nn.15-19 (1976) (narrow focus of class action literature on (b)(3) issues) [hereinafter cited as $D e$ velopments]; see, e.g., Handler, The Shift from Substantive to Procedural Innovations in Antitrust Suits-The Twenty-Third Annual Antitrust Review, 71 ColUM. L. Rev. 1, 4-12 (1971) (cost-benefit analysis of damage class actions on behalf of numerous small claimants discloses that burdens on courts are not offset by negligible benefits for class members, because costs erode recovery); Simon, Class Actions-Useful Tool or Engine of Destruction, 55 F.R.D. $375,377-78$ (1973) ((b)(3) class action has burdened courts with litigation on behalf of class members having small claims and little interest in pursuing them, distorted substantive antitrust law to accommodate class suits, and generated little recovery for class members). 
difficulties attending Rule 23(b)(3) class actions for damages. However, recent Rule 23(b)(2) antidiscrimination cases display glaring inconsistencies with the terms of the rule. The subdivision's restriction of class status to cases in which the appropriate final relief is injunctive or declaratory is often abandoned in order to accord (b)(2) class treatment to Title VII suits seeking class-wide back pay. ${ }^{7}$ In addition, the Rule 23(a) numerosity requirement is distorted or disregarded, ${ }^{8}$ and the 23(a) requirements of commonality, typicality, and class membership ${ }^{9}$ are interpreted in conflicting ways in (b)(2) suits. The discordance in the case law suggests that Rule 23(b)(2) is no longer smoothly "generalized across substantive lines." 10

The Note seeks to reconcile the Rule 23(b)(2) case law ${ }^{11}$ and to illuminate the substance/procedure dynamic that has reshaped the (b)(2) class action rule; the Note argues that the public policy against discriminatory practices ${ }^{12}$ has molded its own procedural rule to conform to the concept of class inherent in the substantive antidiscrimination law. After Part I sets forth the structure of Rule 23 and examines the ambiguity of purpose in the framing of section 23(b)(2), Part II discusses developments in the 23(b)(2) case law that manifest the reshaping of the codified procedural scheme by the mandate of substantive antidiscrimination law. Part III then suggests that the anomalous

7. See pp. 874-78 infra (discussing grant of back pay awards in (b)(2) class actions).

8. See pp. 878-79 infra (discussing disregard of numerosity requirement of Fed. R. Civ. P. 23(a)(1)).

9. See pp. 879-83 infra (discussing conflict over application of typicality, commonality, and class membership criteria of FED. R. Civ. P. 23(a)).

10. Cover, supra note 1 , at 718.

11. Although Title VII actions against employment discrimination constitute the body of law in which Rule 23's requirements have been most consistently violated, the terms of the Rule have also been disregarded in antidiscrimination actions brought under 42 U.S.C. $\$ 1983$ (1970) for violation of the equal protection clause, see, e.g., Jones v. Diamond, 519 F.2d 1090, 1099-1100 (5th Cir. 1975) (trial court directed to read Rule 23(a) numerosity requirement liberally in (b)(2) civil rights suits; action seeking compensatory and punitive damages for named plaintiff and unascertained amounts for class, as well as injunction to reform jail conditions, treated under (b)(2)); Arkansas Educ. Ass'n v. Board of Educ., 446 F.2d 763, 765-66 (8th Cir. 1971) (23(a) numerosity requirement interpreted to allow class consisting of only 20 teachers), and under Title VIII of the Civil Rights Act of 1968, 42 U.S.C. $\$ 3604$ (1970), see, e.g., Weathers v. Peters Realty Corp., 499 F.2d 1197. 1200 (6th Cir. 1974) (23(a) numerosity requirement "is usually satisficd by the showing of a colorable claim by the named plaintiff who is a member of a larger class having potentially similar" housing discrimination action seeking compensatory and punitive damages for class treated under (b)(2)). Thus, although this Note relies on Title VII case law, the analysis is not restricted to the area of employment discrimination.

12. See, e.g., Alexander v. Gardner-Denver Co., 415 U.S. 36, 45 (1974) (Title VIr cmbodies "important congressional policy against discriminatory employment practices"); Sape \& Hart, Title VII Reconsidered: The Equal Employment Opportunity Act of 1972, 40 Geo. WASH. L. REv. 824, 824-45 (1972) (discussing pre.Title vII manifestations of federal government's concern with employment discrimination and detailing legislative history of Title VII in this context). 
23(b)(2) suits can be reconciled by construing the group litigant as a cohesive social entity-an "entity class." 13 The entity class action represents a common law hybrid resulting from the interaction of the federal class action rule with the compelling substantive objectives of Title VII.

\section{The Structure and Purpose of Rule 23(b)(2)}

The elements that were intended to define the Rule 23(b)(2) class action category have repeatedly been ignored. It is therefore useful to identify them and restate the reasons why these factors were thought to mark situations appropriate for representative adjudication.

The federal class action rule establishes two sets of criteria for authorizing class actions. Rule 23(a) establishes mandatory prerequisites applying to all class actions. ${ }^{14}$ These 23 (a) conditions function to define the class ${ }^{15}$ and to ensure adequacy of representation for the class. ${ }^{16}$ Rule 23(b) then divides class actions into three types. ${ }^{17}$ One of these 23(b) categories must be satisfied, in conjunction with the 23(a) prerequisites, for a class action to be maintained.

Rule 23(b) appears on its face to define types of class actions by the nature of the relief sought. Rule $23(b)(3)$ is sometimes denoted the

13. See pp. 885-86 infra (discussing entity class).

14. One concern always present in class actions is manageability. Although such a requirement is only explicitly included in FED. R. CIv. P. 23(b)(3)(D), which applies to actions for money damages, this concern is also tangentially related to the general class action prerequisites of FED. R. Civ. P. 23(a). The latter section promotes manageability by ensuring that class members share common claims and defenses. Moreover, the precise definition of a class in terms of the 23(a) criteria bears upon manageability: problems in identifying class members have been held to make a class suit unmanageable. See, e.g., Lawson v. Brown, 349 F. Supp. 203, 209 (W.D. Va. 1972). But because the Rule calls for no direct assessment of manageability in (b)(2) suits, courts have placed little weight on manageability in (b)(2) class actions seeking class-wide back pay. See note 49 infra (discussing United States $v$. United States Steel Corp., 520 F.2d 1043, 1053 (5th Cir. 1975), cert. denied, 429 U.S. 817 (1976)).

15. Rule 23(a) describes a class as a group litigant composed of numerous individual members related by common questions of law or fact and by typical claims or defenses. See p. 878 infra (quoting rule); 3B Mooke's Fideral PRictice, sipra note 4, I 23.04[1], at 23-113. The parameters of the 23(a) class are delineated by reference to the commonality and typicality of the class representative. See Note, Class Actions: Defining the Typical and Representative Plaintiff Under Subsections (a)(3) and (t) of Federal Rule 23, 53 B.U. L. REv. 406, 413 (1973) ("[T]he class must, of logical necessity, be reasonably coextensive ... with the claim the representative is asserting. . . [ [P]recision in the definition of a class vis-à-vis the representative's status is the very essence of the concept of typicality.")

16. Rule 23(a)(4) addresses adequacy of representation directly by requiring that the representative parties "fairly and adequately protect the interests of the class." Rule 23 (a)(3) typicality also helps ensure adequacy of representation. See Note, supra note 15, at 409 (sections (a)(3) and (a)(4) overlap because both "seek to ensure an .... inquiry into the suitability of the representative to protect the interests of the class").

17. See note 4 supra (quoting rule). 
"damage class action"18 because it authorizes a single lawsuit for monetary redress on behalf of numerous persons having similar disputes with the defendant, when economies of time, effort, and expense would be achieved by representative group litigation. ${ }^{19}$ The (b)(3) class action requirements ${ }^{20}$ ensure that "the efficiency and economy of common adjudication outweigh the difficulties and complexity of individual treatment" ${ }^{\prime 2}$ of class members' claims for pecuniary relief.

In contrast, Rule 23(b)(2) authorizes class treatment when the "class as a whole" appropriately seeks "final injunctive relief or corresponding declaratory relief" from conduct pursued on "grounds generally applicable to the class." 22 Although the Advisory Committee Note recommends Rule $23(\mathrm{~b})(2)$ as the vehicle for injunctive or declaratory relief,, ${ }^{23}$ that can resolve the dispute at one stroke, it also suggests that Rule 23(b)(2) may embrace suits seeking monetary compensation, provided this is not the predominant remedy. ${ }^{24}$ This implies that the essential element of Rule 23(b)(2) may be not the nature of the relief sought, but some other characteristic of the litigation.

In addition to linking Rule 23(b)(2) to cases involving injunctive or declaratory relief, ${ }^{25}$ the draftsmen of the Rule suggested that it should "reach situations where a party has taken action or refused to take action with respect to a class." 26 The Advisory Committee thus did not make clear whether the Rule 23(b)(2) class action centers upon the form of the relief sought, or upon the group nature of the harm

18. E.g., A. Miller, supra note 5, at 40, 47.

19. See, e.g., Advisory Comm. Note, supra note 4, at 102-03; Kaplan, supra note 4, at 390; 7A C. WRIGHT \& A. MILLER, supra note $4, \S 1777$, at 44-46.

20. See note 4 supra (quoting rule).

21. A. Miller, supra note 5, at 49; see Advisory Comm. Note, supra note 4, at 103-01 ((b)(3) class action requires court to find "that the questions common to the class predominate over the questions affecting individual members"; "only where this predominance exists . . . can [economies] be achieved by means of the class-action device").

22. FEo. R. Civ. P. 23(b)(2); see note 4 supra (quoting rule).

23. See Advisory Comm. Note, supra note 4, at 102 ("This subdivision is intended to reach situations where ... final relief of an injunctive nature or of a corresponding declaratory nature . . . is appropriate.")

24. See id. ("The subdivision does not cxtend to cases in which the appropriate final relief relates exclusively or predominantly to moncy damages.")

25. Id. Commentators have emphasized (b)(2)'s relief provision and the portion of the Advisory Committee Note discussing appropriate (b)(2) relicf, and have therefore portrased Rule 23(b)(2) as clearly keyed to the character of the injunctive/declaratory remedy. Sec, e.g., 7A C. Wright \& A. Miller, supra note 4, $\$ 1777$, at 44 (23(b)(2) provides "for the bringing of a class action based on the type . . . of . . . relief being sought"); Conment, Rule 23: Categories of Subsection (b), 10 B.C. Invus. \& CoM. L. REv. 539, 545 (1969) ("(b)(2) is concerned with the type of relicf sought").

26. Advisory Comm. Note, supra note 4, at 102. The Note further explains: "Action or inaction is directed to a class... even if it has taken effect or is threatened only as to one or a few members of the class, provided it is based on grounds which have general application to the class." $I d$. 
rendered when actionable conduct is based "on grounds generally applicable to the class." 27

The cases designated as illustrations of Rule 23(b)(2) in the Advisory Committee Note $^{28}$ and by Reporter Kaplan in his personal discussion of the 1966 Amendments ${ }^{29}$ underscore this ambiguity. These cases were civil rights actions that involved both common relief and group harm. ${ }^{30}$ Moreover, leading cases emphasized different factors to justify class treatment. In one case cited by the Advisory Committee, Potts v. Flax, ${ }^{31}$ the court clearly identified group harm as its justification for class certification. ${ }^{32}$ But Hall $v$. Werthan Bag Corp. ${ }^{33}$ a race discrimination case chosen by Reporter Kaplan to exemplify application of Rule 23 (b)(2), emphasized the nature of the relief sought. ${ }^{34}$

27. FED. R. CIv. P. 23(b)(2); see note 4 supra (quoting rule).

28. See Advisory Comm. Note, supra note 4 , at 102.

29. See Kaplan, supra note 4, at 389 n.128. Kaplan's article is accorded authoritative status due to his role as the Committee's Reporter. The cases cited by these two commentaries on the Rule overlap but are not identical.

30. These cases sought declaratory and injunctive relief to correct discrimination directed against all members of a racial group in school assignment, see, e.g., Buckner v. County School Bd., 332 F.2d 452 (4th Cir. 1964); Potts v. Flax, 313 F.2d 284 (5th Cir. 1963), public facilities access, see Bailey v. Patterson, 323 F.2d 201 (5th Cir. 1963), and employment, see Hall v. Werthan Bag Corp., 251 F. Supp. 184 (M.D. Tenn. 1966); Todd v. Joint Apprenticeship Comm., 223 F. Supp. 12 (N.D. IIl. 1963).

The plaintiffs in each case sought only class-wide declaratory and injunctive relief, i.e., relief awarded "with respect to the class as a whole" without consideration of the particular circumstances of each class member, and for their uniform benefit. See, e.g., Potts v. Flax, 313 F.2d 284, 288-89 (5th Cir. 1963) (dispute and request for injunctive relief did not put at issue "peculiar rights of specific individuals" but instead exclusively raised "common question of law" as to whether school board could constitutionally assign pupils to schools by race); Brunson v. Board of Trustees, 311 F.2d 107, 109 (4th Cir. 1962) (controversy over legality of school segregation did not require determination of "disparate factual controversies" that related to various individual claims, since award of injunctive relief required only resolution of common question of whether school board was assigning pupils involuntarily on basis of race). And in every instance, the party opposing the class had acted on racial grounds that threatened or inflicted harm on all members of the group of blacks against which it was directed.

31. 313 F.2d 284 (5th Cir. 1963).

32. The court reasoned that a suit challenging discrimination "presents more than a claim of invidious discrimination to individuals ... . It involves a discrimination against a class as a class ...." Id. at $289 \mathrm{n.5}$ (emphasis in original). Therefore, injunctive "relief to the class" categorically abolishing racial school assignment was "a good deal more than something merely appropriate." Id. at 289 . Relief narrower in scope covering only named plaintiffs would not have furnished full justice; instead, it would have left other group members unprotected. The desirability of an injunction to shield all putative class members against whom the discrimination was by its "very nature" directed, provided the "most important" reason for upholding class treatment in the (b)(2) situation. Id.; accord, Bailey v. Patterson, 323 F.2d 201, 206-07 (5th Cir. 1963) (applying Potts group harm rationale to public facilities desegregation casc).

33. 251 F. Supp. 184 (M.D. Tenn. 1966).

34. Id. at 186 (injunctive relief, requiring only determination of whether "Damoclean threat of a racially discriminatory policy" hung over class, is suitable for class action; compensatory monetary and seniority relief are too "individual" for class treatment). 
The text of Rule 23(b)(2), the Advisory Committee Note, and the case law thus reflect an ambiguity of purpose $\mathrm{e}^{35}$ that deprives the (b)(2) class action of a clear doctrinal foundation. ${ }^{36}$ It is interesting to trace the results of that ambiguity: the erosion of Rule 23's categories produced by the compelling substantive goals embodied in antidiscrimination law.

\section{Anomalous Developments in Rule 23(b)(2) Employment Discrimination Suits}

The common, or injunctive, relief requirement has been ignored in Title VII ${ }^{37}$ class actions brought under Rule 23(b)(2). In these employment discrimination cases, courts have authorized class status for plaintiffs seeking class-wide monetary relief. In addition, they have disregarded the Rule 23(a) numerosity requirement, and have applied the 23(a) typicality, commonality, and class membership prerequisites inconsistently.

\section{A. Back Pay Awards}

Despite the apparent restriction of Rule 23(b)(2)'s remedy to injunctive relief or corresponding declaratory relief, courts now habitually award back pay as part of the class remedy in Title VII class actions brought under (b)(2). ${ }^{38}$ Courts have rationalized these awards in several

35. The fact that all the cited illustrations were civil rights cases does not suggest that all civil rights cases were intended to be brought under (b)(2) regardless of the form of relief sought. The cited cases sought injunctive or declaratory relief, and it is this element that the Rule's text and the Advisory Committee Note identify as a critical defining aspect of the (b)(2) class action. Moreover, the Advisory Committee's comment that price discrimination suits seeking injunctive relief could be brought under (b)(2), see Advisory Comm. Note, supra note 4, at 102, makes it clear that (b)(2) is not defined in terms of the substantive claims underlying the lawsuit.

36. Examination of the prior federal class action rules also sheds no light on the purpose of 23(b)(2). Section (b)(2) has no antecedent in the original Rule 23. FED. R. Civ. P. 23(a) (1938), 39 F.R.D. 94 (1966); see 3B Moore's Federal. Practice, supra note 4, \$ 23.40[1], at 23-285. No doctrinal continuity is discernible, for the categories in the 1938 class action rule were defined neither in terms of relief nor in terms of injury; instead, the rule emphasized the nature of the rights involved. See Kaplan, supra note 4, at 380 . The 1966 Amendments represented an effort to reconceptualize the class action device. As a resuit, the antecedent classification system does not speak to the ambiguity of Rule 23 (b)(2)'s role. See, e.g., Advisory Comm. Note, supra note 4, at 99; Kaplan, supra note 4, at $376-81$.

37. 42 U.S.C. $\$ 2000 \mathrm{e}$ to $2000 \mathrm{e}-17$ (Supp. V 1975).

38. See, e.g., Senter v. General Motors Corp., 532 F.2d 511, 525 (6th Cir. 1976) ("primary prayer was for injunctive relief and the additional request for back pay does not preclude certification as a 23(b)(2) class action"); 7A C. WRIGHT \& A. Miller, supra note 4, § 1775, at $18 \mathrm{n.31}$ (Supp. 1977) (collecting cases). 
ways. ${ }^{39}$ One justification offered for back pay awards argues that the specification of injunctive or corresponding declaratory relief should be read inclusively, not exclusively. Under this formulation, Rule 23 (b)(2) would permit class actions for back pay as part of a class remedy that also included an injunction or declaratory judgment, provided that monetary relief were not predominantly sought and Rule 23(b)(2)'s criteria were otherwise met. ${ }^{40}$

An obvious potential objection to this inclusive interpretation is that if the classification system of Rule $23(\mathrm{~b})$ centers on the nature of the relief sought, the notion that (b)(2) actions should be understood to include noninjunctive or nondeclaratory forms of class relief vitiates the organization of the rule. ${ }^{41}$ By restricting class relief to the injunctive or declaratory remedies that do not require individualized proof with respect to particular class members' claims, the 23(b)(2) relief provision automatically concentrated the litigation upon common ques-

39. Contrary to the assertion in Rich v. Martin Marietta Corp., 522 F.2d 333 (10th Gir. 1975), the Supreme Court's opinion in Albemarle Paper Co. v. Moody, 422 U.S. 405 (1975), does not "[remove] all doubts as to whether back pay can be awarded under Rule 23(b)(2) as well as Rule 23(b)(3)." $522 \mathrm{~F} .2 \mathrm{~d}$ at 342. Albemarle did not address the issue of awarding back pay in Rule 23(b)(2) class actions. It dealt with the equitable standard for determining whether to award back pay in any case when unlawful discrimination is found. See 422 U.S. at $415-25$.

40. See, e.g., Pettway v. American Cast Iron Pipe Co., 494 F.2d 211 (5th Cir. 1974); Robinson v. Lorillard Corp., 444 F.2d 791 (4th Cir.), cert. dismissed, 404 U.S. 1006 (1971).

41. In keeping with the distinctive character of Rule 23(b)(2) injunctive class actions and with the instruction of the Advisory Committee that (b)(2) does not authorize class actions brought primarily for monetary damages, see Advisory Comm. Note, supra note 4 , at 102 , the section might properly allow a class action seeking injunctive relief for the class and monetary redress for the named parties, but not for unnamed class members. This interpretation would accord independent meaning to the Advisory Committee Note without undermining the pointed reference to injunctive relief in the text of Rule 23(b)(2) itself. In fact, such a bright-line rule concerning the scope of 23(b)(2) was suggested in a series of decisions by Judge Newcomer. See Paddison v. Fidelity Bank, 60 F.R.D. 695, 697 (E.D. Pa. 1973) (taking Advisory Comm. Note to 23(b)(2) "as a fairly clear indication that class actions administered solely under (b)(2) were to remain as free of the pitfalls of past money disputes as is consistent with the complete litigation of the causes of action of the named plaintiffs" and ruling that "pursuant to a (b)(2) designation . . . named plaintiffs may recover past damages but unnamed class members may not"); Rhodes v. Weinberger, 388 F. Supp. 437, 444, rev'd on rehearing, 66 F.R.D. 601 (E.D. Pa. 1975); Dickerson v. United States Steel Corp., 64 F.R.D. 351, 354-55 (E.D. Pa. 1974). This line of cases did not withstand the continued impact of the substantive law on the (b)(2) pro. cedural category that it had sought to resist, and was effectively overruled by the Third Circuit's adoption of an inclusive interpretation of Rule 23(b)(2). Wetzel v. Liberty Mut. Ins. Co., 508 F.2d 239 (4th Cir.), cert. denied, 421 U.S. 1011 (1975); see Rhodes v. Weinberger, 66 F.R.D. 601, 604 (E.D. Pa. 1975) (reconsidering 388 F. Supp. 437 (E.D. Pa. 1975)) ("[T]he Wetzel decision vitiates Paddison's injunctive relief/monetary relief dichotomy, at least in actions traditionally considered equitable in nature.") (footnote omitted). But there are other, unrelated cases relegating back pay claims to class actions certified under (b)(3) without the detailed analysis of Paddison. E.g., Mays v. Motorola, Inc., 14 Fair Empl. Prac. Cas. 1470, 1472 (N.D. Ill. 1977); Piva v. Xerox Corp., 70 F.R.D. 378, 390 (N.D. Cal. 1975). 
tions and ensured the efficient utilization of judicial resources, since separate factual investigations would not overburden the court. ${ }^{42}$ On the other hand, 23(b)(3) contemplated individual questions pertaining to each class member's claim for monetary relief, ${ }^{43}$ and so compelled "special judicial consideration of the relationship of the common to the separate questions posed by the potential class suit" 44 in order to guarantee that the class action would be an efficient device for resolving the dispute. Under the inclusive approach to Rule 23(b)(2), classwide claims for individual monetary relief that may raise problems as to the efficiency of the class action escape screening under the $23(\mathrm{~b})(3)$ criteria. ${ }^{45}$

Less obvious but related problems with the toleration of overlapping Rule 23(b) categories emerge from case law analysis. It is instructive that courts have not attempted to determine the point at which the presence of individual claims for compensation complicates 23(b)(2) actions too severely, ${ }^{46}$ for no such standard presents itself in the Rule. Moreover, the definition of such a standard would represent an invitation to some class litigants to frame their lawsuit in such a way as to meet the Rule 23(b)(2) threshold, and so benefit by (b)(2)'s ample procedural advantages. Unlike Rule 23(b)(3), Rule 23(b)(2) does not

42. See 37 OHo ST. L.J. 386, 393 (1976) (" [1]n a class action where there is no claim for money damages, there are usually few if any issues relating peculiarly to individual members . . . . The interest of every (b)(2) class member . . . is exactly the same-the award of an injunction .... ."); 3B Moore's Federal Practice, supra note 4, f 23.40, at 23-654 (2d ed. 1976) ((b)(2) "final injunctive or corresponding declaratory relief . . does not require that the district court look into the particular circumstances of each member of the class").

43. See Advisory Comm. Note, supra note 4, at 103 (acknowledging "nced, if liability is found, for separate determination of the damages suffered by individuals within the class"); 3B Moore's Federal Practice, supra note 4, 9 23.45[2], at 23-335 n.31 ("[i]n any class action where damages are sought, it is clear that consideration will ultimately have to be given to the various class members' claims on an individual basis, if the class should prevail").

44. 3B Moore's Federal Practice, supra note 4, If 23.45[2], at 23-327; see id. at 23-327 to 28 ("[n]o such supplementary screening beyond $23(\mathrm{a})$ is mandated for actions brought under ... (b)(2) ... because the predominance of the common questions is implicit in the character of those actions" and guarantees efficiency).

45. See Paddison v. Fidelity Bank, 60 F.R.D. 695, 698 (E.D. Pa. 1973)

46. There appears to be no obvious demarcation between (b)(2) and (b)(3) class actions for class-wide monctary relief. Compare Robinson v. Lorrilard Corp., 444 F.2d 791 (4th Cir.), cert. dismissed, 404 U.S. 1006 (1971) (certifying as (b)(2) class action Title VII case for injunctive relief and class-wide back pay) with Robertson v. National Basketball Ass'n., 389 F. Supp. 867, 900 (S.D.N.Y. 1975) (denying (b)(2) class status because monetary relief sought). Moreover, insofar as (b)(2) class actions are identified by a "common claim .. . susceptible to a single proof and subject to a single injunctive remedy," Senter v. General Motors Corp., 532 F.2d 511, 525 (6th Cir. 1976), it would secm that the complexity of administering class-wide back pay relief would transform a (b)(2) class action into a (b)(3) action. 
require personal pretrial notice, ${ }^{47}$ which can be prohibitively expensive, does not allow class members to opt out and thereby deprive the action of requisite numerosity, ${ }^{48}$ and does not authorize a denial of class certification because a class action appears unmanageable or because superior methods of adjudicating the controversy are available..$^{40}$ The inclusive explanation thus engenders inevitable administrative difficulties. Introducing yet another inquiry-whether a case is predominantly one for injunctive relief or for a monetary remedy-merely to locate the action in the appropriate 23 (b) pigeonhole wastes judicial resources in an area already sensitive to such considerations..$^{50}$

An alternative rationale for back pay awards under Rule 23(b)(2) emphasizes the word "damages" in the Advisory Committee's statement that (b)(2) does not extend "to cases in which the appropriate final relief relates exclusively or predominantly to money damages." ${ }^{11}$ Courts

47. See Eisen v. Carlisle \& Jacquelin, 417 U.S. 156, 173-76 (1974) (interpreting Rule 23(c)(2) as requiring personal pretrial notice for each class member who can be identified through reasonable effort in all (b)(3) class actions). Eisen explicitly restricted its holding to the notice requirements of section (c)(2), which apply only to (b)(3) class actions, and did not address notice requirements for (b)(2) class actions. $I d$. at $173-76,177$ n.14.

The federal class action rule does not make individual pretrial notice in (b)(2) class actions mandatory. See, e.g., Robinson v. Union Carbide Corp., 544 F.2d 1258, 1260 (5th Cir. 1977); Wetzel v. Liberty Mut. Ins. Co., 508 F.2d 239, 254-57 (4th Cir.), cert. denied, 421 U.S. 1011 (1975). But see Burwell v. Eastern Airlines, 68 F.R.D. 495, 499 (E.D. Va. 1975) (requiring plaintiffs to provide individual notice to class members in (b)(2) suit).

48. Class members generally cannot opt out of the Rule 23(b)(2) class action. See, e.g., Robinson v. Union Carbide Corp., 544 F.2d 258, 260 (5th Cir. 1977); United States v. United States Steel Corp., 520 F.2d 1043, 1057 (5th Cir. 1975). But see Pettway v. American Cast Iron Pipe Co., 494 F.2d 211, 263 n.154 (5th Cir. 1974) (permitting class members to opt out of (b)(2) class at recovery stage).

49. Concerning manageability, compare United States v. United States Steel Corp., 520 F.2d 1043, 1053 (5th Cir. 1975), cert. denied, 429 U.S. 817 (1976) (in (b)(2) class actions, "proof, causation, and computation problems" posed by class-wide claims for back pay challenging " 'physical and fiscal limitations of the court to properly grant and supervise relief' " may not "operate to preclude" class action) with Eisen v. Carlisle \& Jacquelin, 479 F.2d 1005 (2d Cir. 1973), vacated on other grounds, 417 U.S. 156 (1974) (denying (b)(3) class treatment because of difficulty in adjudicating damages owed to numerous members of class and in apportioning relief systematically). Similarly, the trial court cannot refuse to certify a (b)(2) class action merely because it believes that other available methods to adjudicate the controversy, such as a test case or consolidated individual actions, are superior. See Yaffe v. Powers, 454 F.2d 1362, 1365-66 (lst Cir. 1972) (abuse of discretion in (b)(2) class action for "a court to refuse to certify a class on the basis of . . management problems" and failure of plaintiffs to demonstrate superiority of class action device).

50. See, e.g., 7A C. WRIGHT \& A. Miller, supra note 4, § 1775, at 23 ("Disputes over whether the action is primarily for injunctive or declaratory relief rather than a monetary award neither promote the disposition of the case on the merits nor represent a useful expenditure of energy. Therefore, they should be avoided . . . ."); cf. Handler, supra note 6 , at 12 ("class actions should not be allowed where the costs of administration ... are disproportionate to the probable benefits to individual class members and where the class action will put unmanageable burdens on the federal courts").

51. Advisory Comm. Note, supra note 4 , at 102. 
have suggested that the section excludes monetary damages, but not equitable pecuniary relief such as Title VII back pay. ${ }^{52}$

Despite the acceptance achieved by the equitable relief explanation, ${ }^{53}$ the distinction between equitable monetary redress and damages is not a satisfying rationale for certifying Rule 23(b)(2) suits for classwide back pay. The (b)(2) subdivision is geared to the award of uniform prospective protection for the class upon proof of generally applicable conduct, ${ }^{5 \pm}$ and the language of the Rule is explicitly framed in terms of injunctive rather than equitable relief. ${ }^{55}$

\section{B. Rule 23(a) Prerequisites}

Rule 23(a) states:

One or more members of a class may sue or be sued as representative parties on behalf of all only if (1) the class is so numerous that joinder of all members is impracticable, (2) there are questions of law or fact common to the class, (3) the claims or defenses of the representative parties are typical of the claims or defenses of the class, and (4) the representative parties will fairly and adequately protect the interests of the class. ${ }^{56}$

The existence of a class too numerous for individual joinder to be practical has been considered "perhaps the most fundamental requirement for a class suit." $5 \tau$ Some courts, however, have ruled that numerosity is satisfied in Rule $23(\mathrm{~b})(2)$ suits when only a single

52. See, e.g., Robinson v. Lorillard Corp., 444 F.2d 791, 802 (4th Cir.), cert. dismissed, 404 U.S. 1006 (1971) (leading case) ("The back pay award is not punitive in nature, but equitable-intended to restore the recipients to their rightful economic status absent the effects of the unlawful discrimination. ... [B] ack pay, as one element of the equitable remedy, conflicts in no way with the limitations of Rule 23(b)(2).")

53. See, e.g., Pettway v. American Cast Iron Pipe Co., 494 F.2d 211, 257 (5th Cir. 1974) (adopting holding of Robinson v. Lorillard Corp., 444 F.2d 791, 802 (4th Cir.), cert. dismissed, 404 U.S. 1006 (1971)); Walthall v. Blue Shield, 16 Fair Empl. Prac. Cas. 626, 629 (N.D. Cal. 1977).

54. See p. 872 supra. Commentators have asserted that (b)(2) is intended for situations in which an injunction is the object of class action, and have criticized the majority approach of awarding Title VII back pay in (b)(2) class actions as a misapplication of the class action categories. E.g., Barnard, Tille VII Class Actions: The "Recovery Stage", 16 WMr. \& MARY L. Rev. 507, $519-27$ (1975); Edwards, The Back Pay Remedy in Title VII Class Actions: Problems of Procedure, 8 GA. L. Rev. 781, 797.803 (1974).

55. See Paddison v. Fidelity Bank, 60 F.R.D. 695, 697 n.2 (E.D. Pa. 1973) (class-wide back pay awards are not consonant with language of (b)(2)); 37 OHIO ST. L.J. 386, 395-96 (1976) (characterization of back pay award as equitable and therefore not money damages "mere semantic distinction that should not be accorded significance in interpreting rule 23").

56. Fed. R. Civ. P. 23(a).

57. Developments, supra note 6, at 1454; see 3B MOORE's Federal Practice, supra note 4, I 23.05, at 23-149 (" $[\mathrm{t}]$ he raison d'etre of the class suit doctrine is necessity, which in turn depends upon the question of number"). 
identifiable plaintiff, ${ }^{58}$ or two plaintiffs and two intervenors, ${ }^{59}$ constituted the proffered class.

The treatment of numerosity in many employment discrimination cases suggests that some trial courts, usually without acknowledgment, ${ }^{00}$ have transformed the factual inquiry about the practicability of joinder into a per se rule that a Rule 23(b)(2) action alleging discrimination automatically meets the 23(a) requirement. ${ }^{01}$ Although some trial courts in these civil rights cases have simply lowered the numerosity threshold, ${ }^{62}$ others have hypothesized the existence of future class members. ${ }^{03}$ Appellate courts have not only approved these tactics, but have also suggested that the (b)(2) vehicle is so clearly appropriate to the substantive claims underlying discrimination suits that consideration of the "impracticability of joinder" is unnecessary. ${ }^{04}$ These developments suggest that the courts are granting class status to litigants on grounds other than the demonstrated existence of numerous individuals with similar legal claims against a defendant.

The impact of substantive antidiscrimination law on procedure has been less uniformly manifested with respect to the proper handling of Rule 23(a)(2) commonality, (a)(3) typicality, and class membership

58. Scott v. University of Del., 68 F.R.D. 606, 608 (D. Del. 1975).

59. Sullivan v. Winn-Dixie Greenville, Inc., 62 F.R.D. 370, 374 (D.S.C. 1974).

60. See 7 C. WRIGHT \& A. Miller, supra note 4, $\$ 1771$, at $662-65$ ("most courts do not acknowledge that they are applying a different standard" when they treat Rule 23(a) prerequisites more liberally in suits alleging racial discrimination).

61. See, e.g., Scott v. University of Del., 68 F.R.D. 606, 608 (D. Del. 1975) (numerosity "usually not [barrier] to Title VII class actions since the discrimination which the suit seeks to end is per se based on class characteristics"); Sullivan v. Winn-Dixie Greenville, Inc., 62 F.R.D. 370, 374 (D.S.C. 1974).

62. See, e.g., Sullivan v. Winn-Dixie Greenville, Inc., 62 F.R.D. 370, 374 (D.S.C. 1974) (accepting class of only four identifiable persons); Local 246, Utility Workers Union v. Southern Cal. Edison Co., 2 Fair Empl. Prac. Cas. 328, 330 (C.D. Cal. 1969) ("very nature of the Civil Rights Act contemplates the bringing of a class action by even a small number of discriminated-against persons").

63. See, e.g., McLendon v. M. David Lowe Personnel Serws., 15 Fair Empl. Prac. Cas. 245, 247 (S.D. Tex. 1977) (class includes unnamed and unknown future victims of defendant's discrimination whose joinder is impracticable); Walker v. Styrex Indus., 15 Fair Empl. Prac. Cas. 274, 275-76 (M.D.N.C. 1976) (certifying class of "as few as eighteen" present victims of discrimination since "[f]uture employees can be proper members of . . class in an employment discrimination suit ... [and contribute] to creating so many members as to make joinder impracticable"). Contra, Piva v. Xerox Corp., 70 F.R.D. 378 (N.D. Cal. 1975) (refusing to count future members for numerosity purposes).

64. See, e.g., Horn v. Associated Wholesale Grocers, Inc., 555 F.2d 270, 275 (9th Cir. 1977) ("Title VII . . . [and] 1981 actions in which racial discrimination is present are in their nature class action suits. . . [E]mphasis [on large numbers] appears to be misplaced ... . "); Gay v. Waiters \& Dairy Lunchmen's Union, 549 F.2d 1330, 1332-33 (9th Cir. 1977) (chastising district court for "unduly" emphasizing "the number of potential members in a purported class" and for making numerosity judgment without considering that "class litigation of Title VII claims" facilitates "broad remedial purpose of Title VII"). 
criteria $^{6 \Xi}$ than with respect to numerosity. Commonality and typicality require that a class suit raise common questions and typical group claims or defenses, and that the representative plaintiff be a member of the class. ${ }^{66}$ Some courts have adopted the position that these requirements are satisfied whenever a putative class of plaintiffs claims to be the object of discrimination; ${ }^{67}$ others have been more resistant to the broad, remedial sweep of antidiscrimination law, and have continued to engage in rigorous, case-by-case analysis of the propriety of class action treatment regardless of the substantive claim alleged.

Prior to the Supreme Court's decision in East Texas Motor Freight System, Inc. v. Rodriguez, ${ }^{68}$ a majority of circuit courts adopted the permissive approach to typicality, commonality, and class membership requirements in employment discrimination cases. ${ }^{69}$ This approach allowed that "[f]actual identity between the plaintiff's claims and those of the class he seeks to represent is not necessary" "wo when the plaintiff

65. For discussions of these prerequisites, see generally 3B Moore's Federal Practice, supra note 4, 99 23.03-.07; 7 C. WRIGHT \& A. MILLER, supra note 4, \$\$ 1759-1770.

The 23 (a) prerequisites are intended to align the interests of the named plaintiff with those of the represented class, ensuring each absent member the adequate representation prescribed by the due process clause in order to bind nonappearing persons to the adjudication's outcome. See Hansberry v. Lee, 311 U.S. 32, $41-46$ (1940) (due process requires that absent class members be fully represented by parties sharing same interests).

The requirement that representative plaintiffs be members of the represented class has not been precisely cabined under one of the specific Rule 23(a) prerequisites. See $7 \mathrm{C}$. Wright \& A. Mrller, supra note 4, $\$ 1761$, at 585 . Class membership is also associated with satisfying the injury-in-fact standing requirement of Article III. See East Tex. Motor Freight Sys., Inc. v. Rodriguez, 431 U.S. 395, 403 (1977) (citing Article III standing cases for support in discussion of Rule 23(a) class membership requirement); 7 C. Wrighr \& A. MILLER, supra note $4, \S 1761$, at $589-92$ (relationship of standing to class membership under 23(a)).

66. See note 65 supra (discussing criteria).

67. See, e.g., Presseisen v. Swarthmore College, 14 Fair Empl. Prac. Cas. 1312, 1317 (E.D. Pa. 1976) ("[w] ith respect to the commonality and typicality requirement, . . . where an 'across the board' or permeating policy of discrimination is alleged, both requirements are satisfied").

68. 431 U.S. 395 (1977).

69. Johnson v. Georgia Highway Express, Inc., 417 F.2d 1122, 1124 (5th Cir. 1969), initiated the "across-the-board" doctrine when it reversed the trial court's ruling that a "discharged Negro employee could only represent other discharged Negro employees" contesting racially discriminatory dismissal, and held that Johnson could represent a class of all Negro employees challenging a company-wide policy of racial discrimination "in hiring, firing, promotion, and maintenance of facilities." Id. The court set forth the thesis that the class should be given this broad scope because the suit was an "across the board' attack on unequal employment practices alleged to have been committed ... . pursuant to [a] policy of racial discrimination .... The peculiar rights of specific individuals were not in controversy. It [the suit] was directed at the system wide policy of racial discrimination." "Id. (quoting Potts v. Flax, 313 F.2d 284, 289 (5th Cir. 1963)); see Donaldson v. Pillsbury Co., 554 F.2d 825, 827, 830 (8th Cir.), cert. denied, 434 U.S. 856 (1977) (discharged black female employee, even if hired outside normal channels to do special work, satisfied 23 (a) requirements and could pursue broad-based class action attacking all employment practices allegedly limiting job opportunities for women and blacks).

70. Senter v. General Motors Corp., 532 F.2d 511, 524 (6th Cir. 1976). 
alleges employment discrimination. Although an alleged discriminatory policy or practice might manifest itself against individual class members in a variety of ways, ${ }^{71}$ the permissive approach recognized the named plaintiff as typical insofar as he or she claimed to have been injured by conduct motivated by an unlawful animus and visited upon all members of the proffered class by virtue of their race, national origin, sex, or religion. ${ }^{72}$ Despite the existence of factual variations in the employment circumstances of different workers who experienced discrimination in disparate ways, the necessary common questions were found in the issue of whether the claimed discrimination pervaded the conditions of employment. ${ }^{73}$

The minority of courts maintained a more rigorous approach to the Rule 23(a) requirements, insisting on close factual congruence between claims of the class representative and the other class members, and refusing to assume such congruence simply because the plaintiff's substantive claim involved racial or sex discrimination..$^{74}$ These courts seemed especially concerned that without rigorous enforcement of Rule 23(a)'s requirements, the interests of class members would not be fully safeguarded. ${ }^{7 \bar{s}}$

71. The particular form that employment discrimination takes depends upon the type of job involved, and whether a protested decision pertains to hiring, firing, promotion, or facilities.

72. See note 69 supra (citing cases).

73. See id.

74. See, e.g., Harriss v. Pan Am. World Airways, 74 F.R.D. 24, 41-42 (N.D. Cal. 1977) (interests of representative plaintiff must be squarely aligned with those of represented class by comparing representative's position, occupation, terms and conditions of employment, and circumstances surrounding his individual grievance with situation of those he seeks to represent); Williams v. Wallace Silversmiths, Inc., 14 Fair Empl. Prac. Cas. 301,303 (D. Conn. 1976) (rejecting notion that shared racial characteristics, which were basis for denial of employment opportunity, supplied sufficient commonality and typicality for class certification).

75. See, e.g., Harriss v. Pan Am. World Airways, 74 F.R.D. 24, 38 (N.D. Cal. 1977). Courts applying 23(a) restrictively fear that "overbroad" classes will be permitted under an expansive reading of $23(\mathrm{a})$ and will "result in the loss of claims of absent class members which, had the class been appropriately framed, might well have been successfully asserted." Id. at 43. The greater scope of the class might increase the likelihood that the representative plaintiff would not present all the claims of the diverse class effectively because the claims were not necessary to prove his individual case or he was unfamiliar with them. The res judicata or collateral estoppel effect of the failed action would then deprive class members of their day in court. Although these are genuine concerns, they are better addressed directly by the adequacy of representation requirement, which overlaps with commonality and typicality, see, e.g., 3B Moore's Federal Practice, supra note 4. 9 23.06-2, at 23-185 to -190; Note, supra note 15, at 408-09, and is often stated to require that "(a) the plaintiff's attorney must be qualified, experienced, and generally able to conduct the proposed litigation, and (b) the plaintiff must not have interests antagonistic to those of the class," Wetzel v. Liberty Mut. Ins. Co., 508 F.2d 239, 247 (3d Cir.), cert. denied, 421 U.S. 1011 (1975); see Eisen v. Carlisle \& Jacquelin, 391 F.2d 555, 562 (2d Cir. 1968), vacated on other grounds, 417 U.S. 156 (1974); 3B Moore's Federal Practice, supra note $4,423.07[1]$, at 23-202 to .03 . However, it is also recognized that adequacy of representation has "a broader dimension than the attorncy's competence or absence of 
The conflict between the permissive and the rigorous approaches to the Rule 23(a) prerequisites was not settled by the Supreme Court's treatment of 23(a) in Rodriguez.70 The Court ruled that "the named plaintiffs were not proper class representatives under"77 Rule 23(a) because they were not members of the class they sought to represent and had demonstrated that they would not provide adequate representation for the class. ${ }^{78}$ The Court concluded that

suits alleging racial or ethnic discrimination are often by their very nature class suits, involving classwide wrongs. Common questions of law or fact are typically present. But careful attention to the requirements of Fed. Rule Civ. Proc. 23 remains nonetheless indispensable. The mere fact that a complaint alleges racial or ethnic discrimination does not in itself ensure that the party who has brought the lawsuit will be an adequate representative of those who may have been the real victims of that discrimination. ${ }^{79}$

This passage indicates an awareness of the competing interpretations of Rule 23(a)'s requirements, but does not resolve the debate. The opinion emphasizes that adequacy of representation should not be presumed, but it does not specifically address the other elements of $23(\mathrm{a}) .{ }^{80}$ More-

conflict .... One important aspect ... is that the representative plaintiff will be able to present effectively whatever claims that class may have-through discovery and settlement or trial." Harriss v. Pan Am. World Airways, 74 F.R.D. 24, 43 (N.D. Cal. 1977); see Dolgow v. Anderson, 43 F.R.D. 472, 494 (E.D.N.Y. 1968), rev'd on other grounds, 438 F.2d 825 (2d Cir. 1970) (adequacy of representation requires that representative establish that he is capable of waging real fight by showing not only absence of antagonistic interests, but also interests sufficiently identical to those of absent class members that representative will vigorously prosecute suit on their behaif); Note, supra note 15 , at 410 .

76. The procedural posture in which this case reached the Supreme Couurt was unusual. The trial court denied class status and completed trial on the merits of the named plaintiffs' individual claims, which it rejected. The Fifth Circuit reversed on the class action issue, and certified the class without disturbing the trial court's finding that the named plaintiffs had not suffered discrimination. See East Tex. Motor Freight Sys., Inc. v. Rodriguez, 431 U.S. 395, 398-403 (1977) (recounting procedural history).

77. Id. at 403 .

78. The Court held that at the time of certification the named plaintiffs were not members of the 23(a) class, defined in terms of those who possessed the "same interest" and suffered the "same injury," because prior district court trial of their individual claims had proven them unqualified for the jobs they alleged had been denied them on racial grounds. "Thus, they could have suffered no injury as a result of the alleged discriminatory practices, and they were, therefore, simply not eligible to represent a class of persons who did allegedly suffer injury." Id. at 403-04. The Court found that the plaintiffs would not "fairly and adequately protect the interests of the class" "because they had failed to move for class certification prior to trial on the merits and were in conflict with the majority of the class over the desired relief. Id. at 405 (quoting Rule 23(a)(4)).

79. Id. at $405 \cdot 06$.

80. In Rodriguez, the Court tested whether the named plaintiffs were members of the class they sought to represent by inquiring whether they " "possess[ed] the same interest and suffer[ed] the same injury' as the class members." Id. at 403 (quoting Schlesinger v. Reservists Comm., 418 U.S. 208, 216 (1974)). Class membership implicates the issue of 
over, it suggests that the commonality requirement would typically be satisfied by the "very nature"81 of the plaintiff's substantive claim of discrimination. Since adequacy of representation is a matter of concern in all representative litigation, ${ }^{82}$ Rodriguez's concern with this element hardly mandates a rigorous application of all 23(a) requirements to discrimination suits. Subsequent lower court applications of Rodriguez confirm that the dispute over the application of 23(a) criteria to discrimination suits endures. ${ }^{83}$

whether Rule 23(a) is to be narrowly or broadly construed in defining the same interest and injury, and hence the permissible scope of the class. See, e.g., Hubbard v. Rubbermaid, Inc., 25 Fed. R. Serv. 2d 189, 200 (D. Md. 1978) ("meeting the Rule 23(a) prerequisites depends on the level at which the class and the claim are defined"); 7 C. WRIGHT \& A. MiLler, supra note 4, $\$ 1761$, at 587 ("[w] class often will depend on how the court defines the class"). However, because of the peculiar Rodriguez facts, the opinion provides no instruction as to how the same injury/ same interest standard is to be generally applied. The plaintiffs seeking representative status were not class members because they had not proven they suffered no injury from any aspect of the employer's discrimination prior to class certification. Therefore, the Court did not address what constituted "same injury" to support class membership beyond requiring a viable allegation of injury in fact inflicted in some way by the discrimination. The opinion thus offers no guidance as to whether Rule 23(a) is to be narrowly or broadly construed in defining same interest and injury. See 13 Harv. C.R.C.L. L. REv. 175, 186-87 (1978) (since Court never defined "interest" or "injury," either across-the-board or narrow, same-impact approach to 23 (a) requirements could be justified under Rodriguez).

81. East Tex. Motor Freight Sys., Inc. v. Rodriguez, 431 U.S. 395, 405 (1977).

82. See, e.g., Hansberry v. Lee, 311 U.S. 32, $40-46$ (1940) (general principle of AngloAmerican jurisprudence is that one is not bound by judgment in litigation in which one has not been party or virtually represented); Saylor v. Lindsley, 456 F.2d 896, 900.01 (2d Cir. 1972) (Friendly, J.) (expressing concern over adequacy of representation in stockholder derivative action).

83. Compare Alexander v. Aero Lodge No. 735, 565 F.2d 1364, 1373-74 (6th Cir. 1977) (confining Rodriguez's instructions regarding class membership to situations in which it is conclusively established before class certification that named plaintiffs have not suffered from alleged discrimination, and holding that plaintiffs demonstrated same injuries and interests by complaining "of specific actions of discrimination ... typical of the category of practices raised on behalf of the class") and Vuyanich v. Republic Nat'l Bank, 17 Fair Empl. Prac. Cas. 195, 197 (N.D. Tex. 1978) (certifying broad class because Rodriguez prescribed only that "[a] class representative and a class member ... be similarly, not identically situated" by virtue of same animus) and Dickerson v. United States Steel Corp., 493 F. Supp. 55, 61 (E.D. Pa. 1977) (Rodriguez did not undermine court's earlier certification of across-the-board class because Rodriguez same injury requirement did not mean that "each class member must be virtually interchangeable, with each individual having factually identical claims to that of the named representative") with Doninger v. Pacific Northwest Bell, Inc., 564 F.2d 1304, 1312 (9th Cir. 1977) (Rodriguez directs that "mere fact that an action is founded on Title VII does not guarantee class treatment"; 23(a) criteria restrictively applied to require factual showing of questions of law or fact common to class members rather than only conclusory allegations of sex discrimination) and Hubbard v. Rubbermaid, Inc., 25 Fed. R. Serv. 2d 189, 198, 201 (D. Md. 1978) (Rodriguez modifies across-the-board view of Title VII class actions by balancing liberal treatment of Title VII cases with concern for pitfalls of treating 23(a) criteria too lightly; class limited to employees in named plaintiff's work division) and Carpenter v. Herschede Hall Clock Div., Arnold Indus., 77 F.R.D. 700, 701 (N.D. Miss. 1977) (Rodriguez requires limitation of class to black employees in plaintiff's department). 
III. The Common Law Reformulation of Rule 23(b)(2): The Entity Class Action

\section{A. The Changing Focus of Rule 23(b)(2) in Antidiscrimination Cases}

Case law developments suggest that a distinctive class action is being created by the interaction of Rule $23(\mathrm{~b})(2)$ with substantive antidiscrimination law. This evolving common law category of class action cannot be reconciled with either of the principles that originally defined (b)(2) class actions. The regular grant of Title VII monetary awards to the (b)(2) class litigant demonstrates that this emergent class action is not tied to the form of relief sought; nor does the element of common harm fully explain this type of (b)(2) class action. ${ }^{84}$ Rather, the treatment of Rule 23(a) numerosity, class membership, typicality, and commonality requirements in the employment discrimination case law indicates that in these suits, 23(b)(2) has been shaped by the force of the substantive antidiscrimination law to accommodate the special nature of the groups protected, ${ }^{85}$ and that this common law class action operates under its own set of rules.

The approach to Rule 23(a) requirements in the new class action category formed by the interaction of (b)(2) and employment discrimination law thus reflects the courts' shared understanding that a "suit for violation of Title VII is necessarily a class action as the evil sought to be ended is discrimination on the basis of a class characteristic."86 The courts relax 23(a)'s required proof of a "class," permitting class certification despite the absence of demonstrated impracticability of joinder and the existence of a multitude of discrete factual questions pertaining to individual class members. In this area of law, courts do not find a class by molding an aggregate of numerous individuals into

84. The emerging (b)(2) class action cannot be defined as a discrete class action category by the element of common harm, since this aspect does not distinguish (b)(2) from (b)(3). Common harm can be experienced by (b)(3) class members who scek primarily monetary rather than injunctive relief. See, e.g., Eisen v. Carlisle \& Jacquelin, 391 F.2d 555, 559 (2d Cir. 1968), vacated on olher grounds, 417 U.S. 156 (1974) (class con!posed of all stock traders dealing in odd-lots who allegedly had been injured by cxcessive odd-lot differential charges of brokerage firms).

85. See Griggs v. Duke Power Co., 401 U.S. 424, 429-31 (1971) ("The objective of Congress in the enactment of Title VII ... Was to achiere equality of employment opportunities and remove barriers that ... favor an identifiable group of white employees over other employees .... ."); cf. Fiss, Groups and the Equal Prolection Clause, 5 Pull. \& PuB. AFr. 107, 147.57 (1976) (equal protection clause should be read to provide special judicial protection for disadvantaged social groups).

86. Bowe v. Colgate-Palmolive Co., 416 F.2d 711, 719 (7th Cir. 1969); see Senter v. General Motors Corp., 532 F.2d 511, 524-25 (6th Cir. 1976); Wetzel v. Liberty Mut. Ins. Co., 508 F.2d 239, 250-51 (3rd Cir.), cert. denied, 121 U.S. 1011 (1975); Oatis v. Crown Zellerbach Corp., 398 I.2d 496, 499 (5th Cir. 1968). 
a group litigant by the factual identity of their claims against the defendant. Instead, a class is determined to exist in civil rights cases because "discrimination based on race, sex, or national origin is by definition class discrimination." 87 The substantive law seems to recognize a distinctive kind of class litigant. ${ }^{\text {ss }}$

\section{B. Substantive Law. Procedural Rules, and the Entity Class Action}

Title VII forbids discriminatory employment practices based upon race, color, sex, national origin, or religion. ${ }^{89}$ The substantive law's proscription recognizes that such characteristics identify groups of individuals who are subject to widespread prejudice. The policy against discrimination thus carries with it an implicit conception of class as a social entity. This "entity class" 00 is an a priori class that has an

87. Gay v. Waiters' \& Dairy Lunchmen's Union, 549 F.2d 1330, 1333 (9th Cir. 1977).

88. Concern with the particular nature of the class plaintiff in antidiscrimination suits is most evident in Wetzel v. Liberty Mut. Ins. Co., $508 \mathrm{~F} .2 \mathrm{~d} 239$ (3d Cir.), cert. denied, 421 U.S. 1011 (1975). In Wetzel, the court decided that an employment discrimination action could continue to be maintained under (b)(2) after the "employer's change of discriminatory policy . . . obviated the need for injunctive" protection. Id. at 251. The court explicitly divorced this type of (b)(2) class action from the nature of the relief sought and instead focused on the group character of the litigant. The court reasoned that because the class of women challenging sex discrimination in their employment shared the common characteristic of sex, the class was "cohesive as to the claims [of sex discrimination] alleged in the complaint" and therefore was "particularly fit" for (b)(2) class action treatment. $I d$. at 250 . The cohesive character of the class was not altered by the fact that injunctive protection was no longer necessary. The propriety of (b)(2) class treatment, then, was tied to the substantive cause of action, although the Welzel court did not articulate the relationship between the substantive antidiscrimination law and the character of the (b)(2) class. The case thereby left itself open to the criticism that in shifting the rationale of the (b)(2) category from its distinctive form of relief, it had demolished the (b)(2) class action and made it indistinguishable from the (b)(3) type. See 37 Oнıо ST. L.J. 386 (1976) (criticizing Wetzel for failing to distinguish persuasively (b)(2) from (b)(3) classes).

[T] he mere fact that the class shared a common characteristic cannot really be adranced as the reason why it is cohesive in relation to (b)(3) classes. By the same reasoning, a class of odd-lot traders challenging allegedly excessive odd-lot differentials charged by brokerage firms could be considered equally cohesive. The class of odd-lot traders share a common characteristic, namely, that they all trade in odd lots. However, such a class ... was found by the Second Circuit to be a (b)(3) class in Eisen v. Carlisle \& Jacquelin.

Id. at 393-94. This Note argues that the Welzel (b)(2) class is different from the Eisen (b)(3) class because traits such as race or sex identify preexisting, socially significant classes in a way that trading in odd-lots does not.

89. See note 2 supra.

90. The term "entity class" is derived from Fiss, supra note 85, at 147-57 (discussing social groups deserving special protection under equal protection clause).

There are natural classes, or social groups, in American society [e.g., Blacks, who] ... view themselves as a group; ... [T] Their identity is in large part determined by membership in the group; their social status is linked to the status of the group; and much of our action, institutional and personal, is based on these perspectives . . . . $[.1]$ social group is more than a collection of individuals. . . A social group . . is an 
autonomous identity apart from and prior to any jural relationships created between the class members and an opposing party by the latter's conduct. ${ }^{11}$ The distinct class identity is predicated on a characteristic possessed by all its members, such as race or sex, which defines persons as class members. ${ }^{22}$ Thus, Title VII articulates an important public policy forbidding discriminatory employment practices directed against individuals because of membership in entity classes. ${ }^{93}$ The entity class notion has reshaped the Rule 23(b)(2) class action and helps explain the courts' seemingly anomalous treatment of the 23(b)(2) class action rule in Title VII cases.

The entity class character of the group victimized by discrimination explains the willingness of courts to hypothesize present and future class members. This treatment of the numerosity requirement assumes a class existing over time. Ongoing discrimination against a group will affect class members at a later time. Case-by-case analysis of numerosity is not necessary when an entity class is the litigant because such a class exists without the determination that there are too many persons to be joined.

The entity class construct also explains lax treatment of Rule 23(a)'s commonality and typicality requirements. Regardless of factual dissimilarity in the particular manifestations of the defendant's class bias, the entity class plaintiff suffers the "same injury" 94 as other members of the entity class litigant. He also shares the "same interest"9s as all

entity (though not one that has a physical body). This means that the group has a distinct existence apart from its members, and also that it has an identity.

Id. at 148; cf. Yeazell, Group Litigation and Social Context: Toward a History of the Class Action, 77 Colum. L. Rev. 866, 877 (1977) ("groups involved [in sixteenth and seventeenth century group litigation] existed as social entities independent of the law: suit").

91. See Fiss, supra note 85 , at 148 . The "entity class" is not a collection of persons who are merely fellow travelers united for jural purposes by some common question of law or fact and by typical claims raised by the behavior of the opposing party in the lawsuit.

92. See Hernandez v. Texas, 374 U.S. 475, $478-79$ (1954) ("persons of Mexican descent" held to constitute class cognizable under equal protection clause because of community's attitude); Fiss, supra note 85, at 148 ("much of our action, institutional and personal, is based on" group perspectives).

93. See Senter v. General Motors Corp., 532 F.2d 511, 524 (6th Cir.), cert. denied, 429 U.S. 870 (1976) ("[t]he operative fact in an action under Title VII is that an individual has been discriminated against because he was a member of a class"); Smalls, Class Actions Under Title VII: Some Current Procedural Problems, 25 AM. U.L. Rev. 821, 848 (1976) (members of Title VII class "have suffered discrimination directed at them as a group and as individuals").

94. East Tex. Motor Freight Sys., Inc. v. Rodriguez, 431 U.S. 395, 403 (1977).

95. Id. One commentator has rejected the group wrong justification for the acrossthe-board approach, arguing that such a justification would bestow the right to bring a class suit by virtue of "mere membership in the disadvantaged group," making "the scope of class representation under title VII virtually limitless." 13 HaRv. C.R.C.L. L. 
other members in ending discrimination against the entity class. This interest is stimulated not only by a desire to diminish the immediate harm to himself, but also to better the general social condition of the class with which his personal welfare is ineluctably associated. ${ }^{.6}$

In some circumstances, the entity class construct would restrict the scope of the class that could be adequately represented by the named plaintiffs. ${ }^{97}$ Courts have a responsibility not only to ensure that no

REv. 175, 188-89 (1978). This commentator does, however, accept a permissive approach in cases in which all the claims depend upon the same proof of discriminatory impact. In such cases, he argues, a broad class promotes fairness, by ensuring adequate representation of absent persons whose interests would necessarily be affected by the outcome of the suit, and promotes efficiency, by allowing resolution of all claims that depend on the proof of discriminatory impact. Finally, he argues that such a class promotes the goals of Title VII by permitting a single employee to "fight all discrimination by a particular employer." Id. at 197-98.

This argument clearly exaggerates the expansive effects of the group wrong rationale: all of the plaintiffs in a given class action must still have suffered actual discrimination by an actual employer. Moreover, the alternative rationales offered are unconvincing. Efficiency is not necessarily promoted by a broad class action that must involve individual proof of an entitlement to back pay at the recovery stage. And fairness is not a significant issue here because employees who are excluded from a class by a narrow reading of typicality and commonality are not bound by the action and cannot, therefore, be unduly disadvantaged by its outcome. Finally, the commentator's attempt to justify the across-the-board approach as an effective means of implementing Title VII, id. at 197-99, fails to explain why the criteria of Rule 23 should be read liberally in Title VII cases, but not in all cases involving important public policies. In contrast, the entity class construct links this permissive approach to the unique nature of the classes involved in antidiscrimination suits.

96. Fiss, supra note 85 , at $148-49$ (welfare of individual class members is linked to social condition of group as whole); Smalls, supra note 93, at 842 ("[A Title VII plaintiff] generally has a sense of identity with and an emotional tie to the class which he alleges is the subject of discrimination. In many cases he may be motivated by a personal drive to eradicate general injustice against his class.")

97. The entity class construct should inform, not replace, a court's discretionary judgment regarding the adequacy of representation for a class. See, e.g., Johnson v. Georgia Highway Express, Inc., 417 F.2d 1122, 1126-27 (5th Cir. 1969) (Godbold, J., concurring):

Over-technical limitation of classes by the district courts will drain the life out of Title VII . . . . But without reasonable specificity the court cannot define the class, cannot determine whether the representation is adequate, and the employer does not know how to defend. And what may be most significant, an over-broad framing of the class may be so unfair to the absent members as to approach, if not amount to, deprivation of due process.

For example, if a suit were brought by a white woman to challenge discriminatory employment practices, the entity class theory would militate against defining a single class to include black and Hispanic men protesting racial discrimination as well as female employees challenging sex discrimination. Minority employees and female employees are not members of a single societal entity class, and might well have different interests in a Title VII suit against their employer, both as to the establishment of particular discriminatory practices and as to the desired remedy. Moreover, the special identification of an entity class member with his or her class that helps ensure adequate representation and possession of information about class members' complaints would not be present in the relationship of a white woman and the members of the different entity class of minority employees. Cf. Waters v. Heubelin, 547 F.2d 466, 469-70 (9th Cir. 1975), cert. denied, 433 U.S. 915 (1977) (holding white woman had standing under Title VII to 
direct antagonism exists between the interests of class representatives and class members, but also to "ensure that the constituency of each representative is sufficiently congruent with the interests of the representative that the position of the advocate can safely be taken as a statement of the position of the class as a whole." 98

\section{The Common Law Procedure of the Entity Class Action and the Back Pay Award}

Back pay awards have been assimilated into the newly emergent class action through adoption of a bifurcated trial structure accompanied by flexible notice procedures. These procedural elements, developed in the case law, permit realization both of antidiscrimination policies embodied in Title VII and the interest in procedural fairness, without the burdens imposed by Rule 23(b)(3)'s requirement of manageability and mandatory pretrial notice.

To deal with manageability problems created by individual computation of back pay, courts have "bifurcated" Rule 23(b)(2) trial proceedings into an initial, liability stage that focuses on unlawful injury to and injunctive relief for the class as a whole, and a second, recovery stage that deals with the personal pecuniary claims of class members on an individual basis through a series of claimant-by-claimant proofs. ${ }^{90}$

This bifurcated trial mechanism postpones manageability problems

challenge discrimination against minority employees, but leaving open as separate issue whether plaintiff was adequate representative of class of minority employees for Rule 23 purposes). However, two or more entity classes, each with its own representatives, may be represented in a single action. See Rich v. Martin Marietta Corp., 522 F.2d 533 (10th Cir. 1975) (women, Blacks, and Hispanic Americans, each with their own representative, named plaintiffs, challenged employer's employment practices as discriminating on grounds of sex, race, and ethnicity); Advisory Comm. Note, supra note 4, at 104 (discussing Rule 23(c)(4)).

98. Developments, supra note 6 , at 1476 .

99. Baxter v. Savannah Sugar Ref. Corp., 495 F.2d 437, 443-44 (5th Cir.), cert. denied, 419 U.S. 1033 (1974) (emphasis in original):

A Title VII class action suit presents a bifurcated ... proof problem. Initially, it is incumbent on the class to establish that an employer's employment practices have resulted in cognizable deprivations to it as a class. At that juncture of the litigation, it is unnecessarily complicating and cumbersome to compel any particular discriminatee to prove class coverage by showing personal monetary loss. What is necessary to establish liability is evidence that the class of black employees has suffered from the policies and practices of the particular employer. Assuming that the class does establish invidious treatment, the court should then properly proceed to resolve whether a particular employee is in fact a member of the covered class, has suffered financial loss, and thus [sic] entitled to back pay or other appropriate relief.

See International Bhd. of Teamsters v. United States, 431 U.S. 324, 360-62 (1977); United States v. United States Steel Corp., 520 F.2d 1043, 1053-54 (5th Cir. 1975), cert. denied, 429 U.S. 817 (1976). 
involved in individual determinations of back pay until after discrimination against the class has been proven. ${ }^{100}$ Although individual determinations of back pay remain after class-based discrimination has been found, efficiency with respect to individualized proof and computation of back pay is subordinated to Title VII's policies of making victims of discrimination economically whole. ${ }^{101}$

A generally accepted notice procedure in the entity class action has not yet evolved. It would seem that class members should receive notice to appear and present their individual claims for monetary relief after liability has been established, and before the recovery stage. However, some courts have stated that no notice is required, even in Rule 23 (b)(2) cases seeking class-wide back pay. ${ }^{102}$ When notice has been required, the nature of the notice, its timing, and the party responsible for its cost have varied. Some courts require plaintiffs to provide preliability-stage notice to all class members. ${ }^{103}$ Others accept newspaper and plant-posting notice. ${ }^{104}$ And at least one court delayed notice until

100. Liability may be proven by nonindividualized evidence, such as statistics probative of "the defendant's broad employment policies and practices." United States v. United States Steel Corp., 520 F.2d 1043, 1053 (5th Cir. 1975), cert. denied, 429 U.S. 817 (1976); see International Bhd. of Teamsters v. United States, 431 U.S. 324, 337-40, 357-62 (1977) (prima facie case of discrimination may be established by statistical proof without presenting specific evidence of discrimination against individuals seeking back pay, since focus is on pattern of discriminatory decisionmaking rather than on individual employment decisions).

101. See Albemarle Paper Co. v. Moody, 422 U.S. 405, 421 (1975) ("given a finding of unlawful discrimination, backpay should be denied only for reasons which, if applied generally, would not frustrate the central statutory purposes of eradicating discrimination throughout the economy and making persons whole for injuries suffered through past discrimination"). The leading back pay cases overcome (b)(2)'s limitations on relief by appealing to the importance of curing class discrimination, whatever the form of remedy, see, e.g., Pettway v. American Cast Iron Pipe Co., 494 F.2d 211, 257 (5th Cir. 1974); Robinson v. Lorillard Corp., 44 F.2d 791, 802 (4th Cir.), cert. dismissed, 404 U.S. 1006 (197I) (ruling that class-wide back pay "intended to restore recipients to their rightful cconomic status absent the effects of unlawful discrimination" did not conflict with (b)(2)'s limitations because final injunctive relief appropriate), and without regard to management difficulties presented by individual computation of back pay, see, e.g., United States v. United States Steel Corp., 520 F.2d 1043, 1053 (5th Cir. 1975), cert. denied, 429 U.S. 817 (1976) (class-wide relief to be awarded in (b)(2) Title VII class action even if it raised manageability difficulties). Another policy of Title VII served by the subordination of efficiency concerns after liability has been established is the goal of eliminating employment discrimination by providing an incentive, through the threat of back pay liability, for employers and unions to rid themselves of discriminatory practices voluntarily. See Albemarle Paper Co. v. Moody, 422 U.S. 405, 421 (1975).

102. See, e.g., Bolton v. Murray Envelope Corp., 553 F.2d 881, 883-84 (5th Cir. 1977); Robinson v. Union Carbide Corp., 544 F.2d 1258, 1260 (5th Cir. 1977).

103. See, e.g., Women's Comm. for Equal Employment Opportunity v. National Broadcasting Co., 71 F.R.D. 666, 671 (S.D.N.Y. 1976); Burwell v. Eastern Airlines, 68 F.R.D. 495, 499 (E.D. Va. 1975).

104. See, e.g., Ellison v. Rock Hill Printing \& Finishing Co., 64 F.R.D. 415, 417-18 (D.S.C. 1974). 
the recovery stage, and imposed the costs of individual notice on the discriminating defendant. ${ }^{10 \overline{5}}$

This last approach is most appropriate. Providing class members with individual notice of their entitlement to come forward and present claims for back pay meets any due process notice requirement for binding all class members. ${ }^{106}$ Hopefully, future case law developments will clearly establish this notice procedure as part of the common law class action for antidiscrimination suits that seek both injunctive and monetary relief.

\section{Conclusion}

An ambiguity of purpose plagued Rule 23(b)(2) from its inception. ${ }^{107}$ The procedural device was not firmly grounded in a definite concept of class. But Title VII's antidiscrimination mandate embodies a strong notion of class as a preexisting, socially real group that is subject to harmful treatment. ${ }^{108}$ In the encounter between (b)(2) and Title VII, the case law has identified a new class action. This class action enjoys the presumption of a 23(a) class, obviating analysis of 23(a) elements other than adequacy of representation, ${ }^{109}$ and encompasses all forms of relief necessary to redress discrimination suffered by individuals by virtue of their entity class membership. A common law category departing from the Rule has been defined by courts in order to provide a

105. Meadows v. Ford Motor Co., 62 F.R.D. 96, 102 (W.D. Ky. 1974), aff'd as modified on other grounds, 510 F.2d 939 (6th Cir. 1975), cert. denied, 425 U.S. 998 (1976).

106. Cf. Mullane v. Central Hanover Bank \& Trust Co., 339 U.S. 306, 318-20 (1950) (in action to settle accounts of common trust fund, due process requires notice reasonably calculated to reach interested parties).

Notice need not be given until after the liability stage, since prior to adjudication of individual back pay claims at the recovery stage, all class members share a common interest in establishing the existence of discrimination. See Advisory Comm. Note, supra note 4, at 106 ("In the degree that there is cohesiveness or unity in the class and the representation is effective, the need for notice to the class will tend toward a minimum.") Moreover, by delaying notice to the individual class members until after a determination on the merits has established the defendant's liability for discrimination, the cost of notice may be imposed upon defendants, thus avoiding the cost barrier to implementation of Title VII's policies by private party litigation. Cf. Eisen v. Carlisle \& Jacquelin, 417 U.S. 156, 177 (1974) (prohibiting shift of notice costs to defendants prior to final determination on merits).

107. See pp. 872.74 supra.

108. See notes 86 \& 87 supra (citing cases that hold racial or sexual discrimination proscribed by Title VII is inherently class-based).

109. Adequacy of representation, assessed in terms of absence of antagonistic interests, knowledge of diverse claims of all class members, competency of counsel, and a commitment to present the case of the whole class vigorously of course remains vital even when a class is presumed to exist. 


\section{Rule 23(b)(2)}

process more responsive to the true character of the class litigant bringing an antidiscrimination cause of action..$^{110}$

The case law thus teaches that the aspiration to achieve procedural instruments "generalized across substantive lines"111 has not been fulfilled in the case of the class action rule. The force of the substantive law has not been denied: "[T]he river of litigation constantly erodes the architecture of process-oriented codes, leaving us with the case law incidents of application." 112

110. The common law alteration of procedural rules to accommodate substantive ends parallels the adjustment by courts of substantive laws to meet changing social needs. In his recent Holmes Lectures, Professor Calabresi discussed the role of court-made law in the modern era when so much American law is statutory, and suggested that courts continue to treat some statutes as part of the common law, subject to incremental judicial updating to avoid "legal petrification." G. Calabresi, The Common Law Function in the Age of Statutes (Holmes Lectures, Harvard Law School, unpublished manuscript, Mar. 1977).

111. Cover, supra note 1 , at 718 .

112. Id. at 732 . 